\title{
Становление и развитие экономической науки в Туве (1953 - наст. вр.)
}

\section{Галина Ф. Балакина}

Тувинский институт комплексного освоения природных ресурсов Сибирского отделения Российской академии наук, Российская Федерация

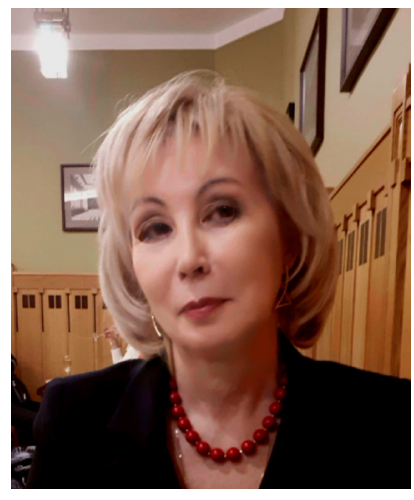

ведомствами.

Современный этап развития экономической науки в Туве отличается значительным количеством специалистов с высшим экономическим образованием, исследователей с учеными степенями. Значительное их число работает в Тувинском институте комплексного освоения природных ресурсов СО РАН.

Ключевые слова: Тува; наука Тувы; тувиноведение; история экономики; история науки; история Тувы; ТувИКОПР СО РAH

В статье анализируются процессы формирования и развития экономической науки в Туве. Выделены три этапа: 1953-1996 г2. - формирование основ системы экономических исследований; 1997-2005 г2. - создание в республике базы увеличения численности специалистов с высшим экономическим образованием; с 2006 г. - по настоящее время - расширение тематики экономических исследований, определение основных направлений, организационных форм и перспектив экономической науки в республике.

На первом этапе экономические исследования проводились в рамках работы сектора экономики Тувинского научно-исследовательского института языка, литературы и истории. Ученые привлекались для изучения вопросов преобразования Тувинской автономной области в Тувинскую АССР, отрабатывались формы взаимодействия органов управления и деятелей экономической науки. Первые диссертации по проблемам экономики Тувы были защищены в 1960-1970-х г2.

В период с кониа 1990-х годов по наст. время стали готовиться спеииалистыэкономисты, ученые. Они составляют профессиональное ядро в сфере управления предприятиями, отраслями, финансовыми организациями, министерствами и 


\title{
The rise and development of the science of economics in Tuva: 1953 to present
}

\author{
Galina F. Balakina \\ Tuvinian Institute for Exploration of the Natural Resources, Siberian Branch, Russian Academy of Sciences, \\ Russian Federation
}

Focusing on the rise and development of economics in Tuva, the article traces three stages in its history: 1953 to 1996, when the foundations of systemic economic studies were laid; 1997-2005, when the numbers of economics majors increased; the latest one started in 2006, when the topic range of studies in economics began to expand, and the main directions, organizational structures and prospects of economics in the region were redefined.

At the earliest stage, economic research was held at the Sector of Economics, Tuvan Research Institute of Language, Literature and History. Economists were consulted when the decision to raise the status of Tuvan Autonomous Oblast' to Tuvan ASSR was being pondered, and the forms of interaction between administrative bodies and researchers in economics were ultimately developed. In 1960s and 1970s the first dissertations of Tuvan economy were defended.

The second stage, which started in late 1990s, saw the much-improved training of economists and other type of researchers. They now form the core of professionals managing enterprises, industry branches, financial institutions, ministries and government agencies.

At the contemporary stage of the science of economics in Tuva, the number of professional economists with a university degree is quite high, as well as that of academic researchers. Many of them are on the staff list of Tuvinian Institute for Exploration of the Natural Resources SB RAS.

Keywords: Tuva; science in Tuva; Tuvan studies; history of economics; history of science; history of Tuva; Tuvinian Institute for Exploration of the Natural Resources $S B R A S$

For citation:

Balakina G. F. The rise and development of the science of economics in Tuva: 1953 to present. The New Research of Tuva, 2020; 2: 276-290. (In Russ.). DOI: www.doi.org/10.25178/nit.2020.2.19

\section{Введение}

В 2020 году научная общественность Тувы отмечает 45 лет становления и развития академической науки в республике, одним из важных направлений которой была экономическая наука. Те или иные аспекты развития экономической науки, в особенности в виде важных вех - защит диссертаций по экономическим наукам, уже затрагивались в ряде исследований по истории формирования интеллигенции в Туве (Харунов, 2009; Харунова, 2011). Однако история развития экономической науки до недавнего времени не становилась предметом глубоких исследований. Среди отдельных публикаций о развитии экономических исследований можно назвать в том числе работу автора данной статьи (Балакина, 2011), а также В. К. Севека (Севек, 2015), в которых определены этапы и описаны процессы формирования экономических исследований в регионе.

В данной работе мы проанализируем состояние развития экономической науки в Туве, систематизируем факторы ее развития, а также определим направления совершенствования. Источниковой базой для нас выступили научные публикации по экономике, информация о защищенных диссертациях в области экономических исследований и локализированных по Туве (в том числе обобщенная в: Библиографический указатель, 2000), а также личные воспоминания автора, непосредственно принимавшего участие в развитии отрасли в регионе в последние тридцать лет.

По нашему мнению, могут быть определены следующие этапы развития экономической науки в Республике Тыва:

1) 1953-1996 гг. - формирование основ системы экономических исследований. В данный период рассматривались методы экономического анализа регионального развития в рамках исследований сектора экономики ТНИИЯЛИ (1953-1974 гг.); открытие Тувинской экономической лаборатории 
Института экономики и организации промышленного производства СО АН СССР (1975 г.) для расчетов по строительству железной дороги в регион, определения основных направлений вовлечения природных ресурсов в хозяйственный оборот, путей решения проблем развития экономики и социальной сферы региона;

2) 1997-2005 гг. - создание в республике базы увеличения численности специалистов с высшим экономическим образованием: начало выпуска Тувинским государственным университетом специалистов по двум специальностям экономического профиля, увеличения притока дипломированных экономистов в республику;

3) С 2006 г. - по настоящее время: расширение тематики экономических исследований, определение основных направлений, организационных форм и перспектив экономической науки в республике. В 2006 г. формирование приоритетных направлений региона осуществлено на базе результатов экономических исследований для разработки Стратегии социально-экономического развития Республики Тыва на период до 2020 года. Отмечается существенное увеличение количества работников с высшим экономическим образованием и исследователей-экономистов с учеными степенями.

Рассмотрим каждый из этих выделенных этапов подробнее.

\section{Формирование основ системы экономических исследований (1960-1996)}

Отсчет первого этапа развития экономической науки в Туве мы начинаем с 1953 г., поскольку именно в этом году по инициативе П. А. Шахуновой, одной из первых ученых исследователей экономики республики, был организован отдел экономики Тувинского научно-исследовательского института языка, литературы и истории (ТНИИЯЛИ), затем - сектор экономики. С этого времени в главном периодическом рецензируемом издании института - «Ученых записках ТНИИЯлИ» - регулярно выходят статьи с анализом экономических процессов развития республики, написанные сотрудниками отдела экономики. Также в этот период ученые привлекались для изучения вопросов преобразования Тувинской автономной области в Тувинскую АССР, отрабатывались формы взаимодействия органов управления и деятелей экономической науки.

В эти годы закладывалась основа для межотраслевых, межведомственных обсуждений проблем перспективного развития регионов России, и Тувы в частности. «Важной площадкой для таких обсуждений, - указывает А. Д. Бегзи, - были совещания и конференции по развитию производительных сил. В Туве в советское время было проведено четыре таких форума: в 1958 г., 1974 г., 1980 и 1988 гг.» (Балакина, Бегзи, 2016: 134). Наряду с работниками органов управления СССР и РСФСР, ведущими специалистами академических и отраслевых институтов, активное участие в научно-практической конференции 1974 г. и совещаниях 1980-1988 гг. принимали сотрудники научных учреждений Тувы: Тувинского НИИЯЛИ, сельскохозяйственной опытной станции, а также организованных в 1970-1980-е гг. подразделений Сибирского отделения АН СССР - Тувинской экономической лаборатории Института экономики и организации промышленного производства СО АН СССР, Тувинской геологической лаборатории Института геологии и геофизики СО АН СССР, Тувинского комплексного отдела СО АН СССР, позже преобразованного в Тувинский институт комплексного освоения природных ресурсов СО РАН (там же: 138).

Первые диссертации по проблемам экономики Тувы были защищены в 1960-х и 1970-х годах Л. И. Тульчинским (Тульчинский, 1961), В. В. Осиповой (Осипова, 1963), А. Г. Ковалевым (Ковалев, 1963), В. П. Солдатовым (Солдатов, 1967), Ю. Г. Полуляхом (Полулях, 1974), Д. Л. Тинмеем (Тинмей, 1977), что стало важной вехой в развитии экономической науки в республике. Появление дипломированных высококвалифицированных специалистов по экономике создало базу для повышения уровня научных обоснований путей и перспектив совершенствования социально-экономических процессов в регионе.

Здесь следует отдельно отметить защиту диссертации на соискание ученой степени кандидата географических наук К. О. Шактаржиком в 1966 г. (Шактаржик, 1966), который работал в секторе экономики ТНИИЯЛИ с 1966 г., а позднее его возглавил (в 1967-1968 гг.).

При этом, подчеркнем, что первым дипломированным ученым - кандидатом экономических наук - тувинцем стал В. А. Копеел. Он защитил в 1968 г. диссертацию на тему «Особенности создания социалистической экономики в Туве» (Копеел, 1968).

Копеел Василий Амырдаевич (1931-1984) - уроженец Тес-Хемского района Тувинской АССР (фото 1). Сирота, с детства стремился к знаниям. Русский язык выучил самостоятельно по книгам, грамотно без 


\section{НОВЫЕ ИССЛЕДОВАНИЯ ТУВЫ}

www.nit.tuva.asia

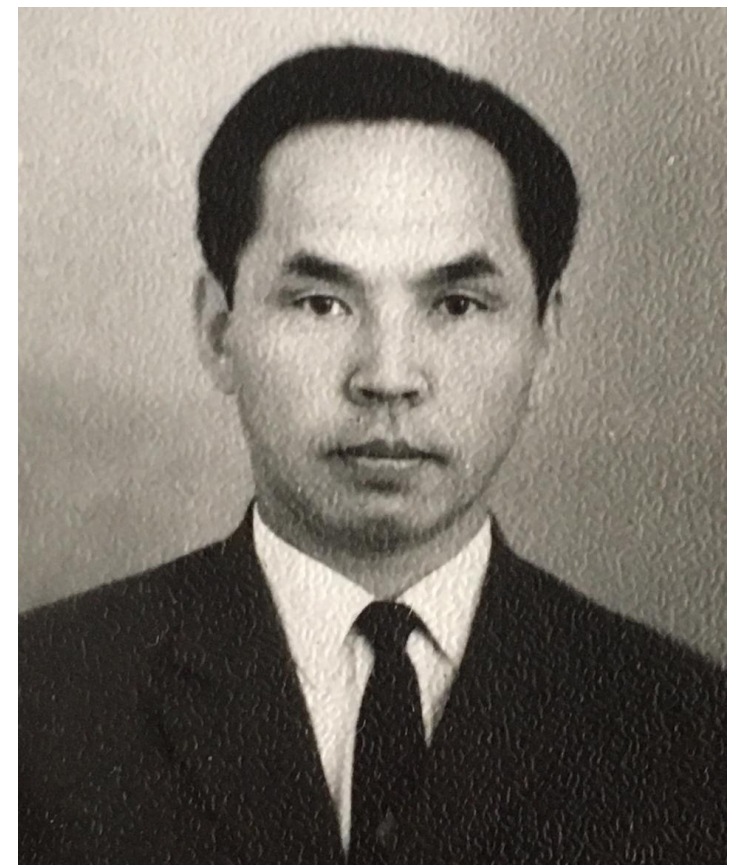

Фото 1. Василий Амырдаевич Копеел.

Фото из личного архива семьи Копеел предоставлено Л. В. Копеел.

Photo 1. Vasily Amyrdaevich Kopeel.

Photo courtesy of L. V. Kopeel from the personal archive of the Koeyel family.

ошибок писал, хотя говорил с акцентом. После окончания Самагалтайской средней школы обучался в Кызылском педагогическом училище, которое окончил в 1954 г. Затем обучался в Высшей партийной школе в г. Красноярске. Работал учителем, заведующим райОНО (районным отделом народного образования), директором школы, лектором Тувинского обкома КПСС. В 1965-1968 гг. учился в аспирантуре Академии общественных наук при ЦК КПСС (г. Москва). После завершения аспирантуры и защиты в Академии общественных наук при ЦК КПСС диссертации «Особенности создания социалистической экономики в Туве» на соискание ученой степени кандидата экономических наук в 1968 г. был направлен на работу в Кызылский государственный педагогический институт, где работал старшим преподавателем, в 1971-1984 гг. заведовал кафедрой марксизма-ленинизма.

Наиболее заметными научными трудами В. А. Копеела являются: монография «Создание социалистической экономики в Туве» (Копеел, 1971), соавторство в коллективной монографии «Экономика Тувинской АССР» (Экономика Тувинской АССР, 1973), соавтор учебного пособия для средней школы «Наша Тува» (1981г.). За 1966-1984 гг. он опубликовал ряд научных статей по истории социально-экономического развития Тувы. Также В. А. Копеел участвовал в составлении «Русско-тувинского словаря общественно-политических терминов» (Русско-тувинский ..., 1966, 1979). Отличительной чертой исследований ученого является систематизация событий экономической истории Тувы, определение на тувинском языке понятий, характеризующих экономические процессы.

К заслугам В. А. Копеела можно также отнести воспитание в своих детях интереса к исследовательской работе: двое из троих детей защитили кандидатские диссертации. Старшая дочь Л. В. Копеел в 1986 г. в НИИ общей и педагогической психологии (г. Москва) защитила диссертацию «пихологические особенности развития мотива общественно-полезной деятельности подростков» на соискание ученой степени кандидата психологических наук. Сын Алексей Васильевич Копеел в 1991 г. в Московском государственном университете им. М. В. Ломоносова защитил диссертацию на тему «Взаимодействие внутрифирменного и рыночного ценообразования в условиях современного капитализма» на соискание ученой степени кандидата экономических наук (Копеел, 1991).

В целом, для первого этапа характерно начало экономических исследований в рамках работы сектора экономики ТНИИЯЛИ. Создание творческого коллектива ученых и практиков для подготовки монографии «Экономика Тувинской АССР», в который вошли проф. С. В. Клопов, к. г. н. К. О. Шактаржик, д. и. н. Н. А. Сердобов, к. э. н. В. А. Копеел, к. э. н. В. П. Солдатов, к. г.-м. н. К. С. Кужугет, П. А. Шахунова, Г. Н. Долгополов, Т. И. Воронков, С. С. Сат и др. (Экономика Тувинской АССР, 1973: 3-8), позволило выпустить книгу, дающую полное энциклопедическое представление об уровне развития отраслей реального сектора экономики 1970-х годов, обобщенную характеристику ресурсов республики - минеральных, лесных, земельных, трудовых, описание истории народного хозяйства Тувы, особенности функционирования отраслей экономики. Монография стала классическим трудом по экономике республики. За почти полвека, прошедшие после ее выпуска, аналогичных изданий в Туве до сих пор не вышло, хотя потребность в них крайне велика.

Также в этот период было осуществлено повышение организационного статуса и расширение экономических исследований как результат создания подразделения экономической науки в рамках Академии наук СССР - Тувинской экономической лаборатории Института экономики и организации промышленного производства СО АН СССР. Возглавил ее к. г. н. К. О. Шактаржик, ранее работавший заведующим сектором экономики Тувинского НИИЯЛИ. В лабораторию были приглашены и в течение многих лет работали кандидаты геолого-минералогических наук К. С. Кужугет (первый ученый-геолог 
среди тувинцев), В. И. Лебедев, В. В. Зайков; геологи В. Г. Тюлькин, В. Н. Гречищева, Г. И. Добрянский, лаборанты Л.С. Коваленко и З.Я.Сайзу; экономисты А.Д. Бегзи, Г. Ф. Киприевская (Балакина), И. А. Безъязыкова, секретарь руководителя С. О. Хураган.

Заметный вклад в исследования лаборатории внес Александр Донгакович Бегзи, экономист выпускник Института экономики народного хозяйства им. Г. В. Плеханова (ныне - Российский экономический университет им. Г. В. Плеханова), автор более 50 научных публикаций по вопросам социально-экономического развития региона, включая участие в пяти коллективных монографиях (в т. ч.: Балакина, Бегзи, 2016), позднее работавший заместителем министра и министром экономики Республики Тыва (1994-1997 гг.).

Многое в это время было сделано для взаимодействия новой научной организации с республиканскими органами власти. К. О. Шактаржик, А. Д. Бегзи и другие сотрудники лаборатории постоянно привлекались Тувинским областным комитетом КПСС и Советом Министров Тувинской АССР к подготовке аналитических материалов по развитию производительных сил Тувы, проведению различных мероприятий, в том числе научно-практических совещаний по проблемам перспективного развития народного хозяйства Тувинской АССР, которые были проведены в Кызыле в 1980 и 1988 гг. с участием ведущих научных организаций и органов государственного управления СССР и РСФСР (Бегзи, Балакина, 2016: 11).

Лаборатория занималась исследованием проблем и перспектив социально-экономического развития Тувинской АССР на краткосрочную (до 1990 г.) и на долгосрочную (до 2010 г.) перспективу. В качестве стратегического направления развития экономики рассматривались проблемы комплексного развития производительных сил территории, одним из инструментов которого могло стать создание Тувинского территориально-производственного комплекса (ТувТПК) на базе развития горнодобывающих и агропромышленных предприятий. Изучались целесообразность строительства железной дороги в Туву, вопросы освоения природных ресурсов республики, формирования трудовых ресурсов, функционирования отраслей народного хозяйства. Результаты коллективных и личных исследований отражены в ряде научных отчетов, имеющих гриф «Для служебного пользования» и поэ-

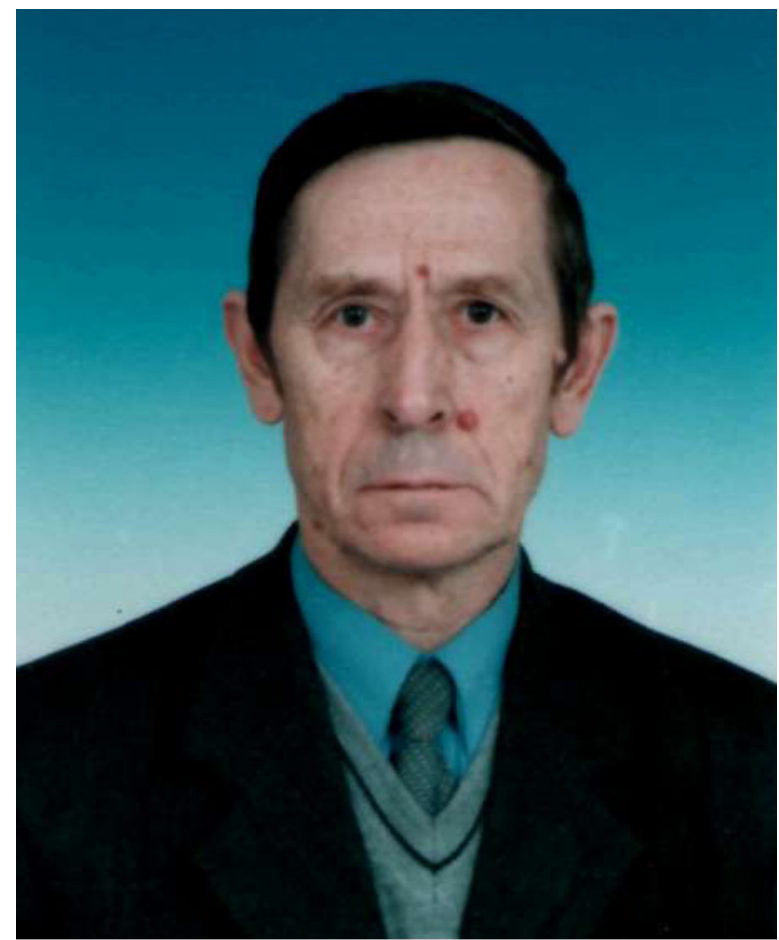

Фото 2. Юрий Георгиевич Полулях. Фото из личного архива семьи Полулях предоставлено Л. Ю. Ададимовой. Photo 2. Yuri Georgievich Poluliakh. Photo courtesy of L. Yu. Adadimova from the personal archives of the Poluliakh family. тому не опубликованных в открытой печати, а также в научных статьях, материалах конференций, разделах коллективных монографий «Городское население Тувинской АССР» (Городское население..., 1981), «Очерки социального развития Тувинской АССР» (1983), «Молодежь Тувы. Социальный портрет» (Молодежь Тувы ..., 1988) и других (Шактаржик, Бегзи, Урбанаев, 1980).

Сотрудники Тувинской экономической лаборатории Института экономики и организации промышленного производства СО АН СССР К. О. Шактаржик, В. И. Лебедев, К. С. Кужугет, В. В. Зайков, А. Д. Бегзи принимали активное участие в подготовке научнопрактических совещаний по развитию производительных сил Тувы, которые были проведены в Кызыле в 1980 и 1988 гг., конференциях по развитию производительных сил Сибири, научно-практических конференциях по развитию промышленности Тувы, проведенных в Хову-Аксы и Ак-Довураке.

Важной вехой в становлении экономической науки Тувы следует назвать защиту первой докторской диссертации. Первым доктором экономических наук республики стал Ю.Г. Полулях (род. 24.11.1940), защитивший диссертацию в 1993 г. (фото 2).

Юрий Георгиевич Полулях родился в Саратовской области. Получил высшее образование инженера-механика в Саратовском институте механизации сельского хозяйства (1967 г.). После окончания вуза с 
отличием, отказавшись от учебы в аспирантуре, он приехал на работу в Тувинскую сельскохозяйственную опытную станцию. Позднее получил образование инженера-экономиста в Красноярском сельскохозяйственном институте (1970 г.). Диссертацию «Пути повышения использования машинно-тракторного парка в земледелии (на примере совхозов Тувинской АССР)» защитил во Всесоюзном НИИ экономики сельского хозяйства (г. Москва) в 1974 г. (Полулях, 1974).

Затем ученый увлекся исследованием рациональной оценки земель, проблемами земельных отношений в современной России, которые и стали его «визитной карточкой». Долгие годы он руководил Тувинским комплексным отделом Сибирского НИИ экономики сельского хозяйства Сибирского отделения РАСХН, совмещая с работой советника по экономическим вопросам Председателя Правительства Тувы. Диссертацию «Теоретические и методические основы экономической оценки сельскохозяйственных угодий и проблемы ее использования» на соискание ученой степени доктора экономических наук Юрий Георгиевич защитил в 1993 г. в Сибирском НИИ экономики сельского хозяйства СО РАСХН в г. Новосибирске (Полулях, 1993).

Ю. Г. Полулях - автор более 100 научных работ, из них 7 монографий. Хотелось бы выделить две монографии: «Региональные аспекты стимулирования роста промышленного производства налоговыми преференциями в Республике Тыва» в соавторстве с Т. М. Ойдуп, В. И. Лебедевым, Л. Ю. Ададимовой (Полулях и др., 2007) и «Состояние социальной инфраструктуры Сибирского федерального округа» - в соавторстве с Т. М. Ойдуп и Л. Ю. Ададимовой (Ойдуп, Полулях, Ададимова, 2011). В первой книге на основе обширного фактологического материала сделан анализ состояния развития промышленных предприятий республики, выявлены проблемы и определены пути их решения. Авторы обосновывают меры по снижению налоговых и затратных нагрузок на промышленные предприятия в целях повышения эффективности хозяйственного комплекса Республики Тыва. Во второй книге рассматриваются результаты исследований на основе применения ГИС-технологий и факторного анализа динамики развития социальной инфраструктуры регионов Сибири за 1990-2008 гг., сделаны выводы о необходимости совершенствования дифференциации федеральной финансовой поддержки регионов для поддержания и развития объектов социальной инфраструктуры сибирских территорий.

Ю. Г. Полуляху посвящена статья в Государственной книге Республики Тыва «Заслуженные люди Тувы XX века», что приравнивается к государственной награде Тувы (Заслуженные люди ..., 2004: 145).

В настоящее время ученый живет в г. Саратове, работает главным научным сотрудником Поволжского НИИ экономики и организации АПК РАН. Следует отметить, что его дочь Л. Ю. Ададимова также увлеклась экономическими исследованиями и в 2019 г. защитила диссертацию «Оценка стоимости сельскохозяйственных угодий и использование её результатов в регулировании агробизнеса» на соискание ученой степени доктора экономических наук. Оба ученые не потеряли интереса к проблемам Тувы и до сих пор сотрудничают с ТувИКОПР СО РАН.

Среди тувинцев первым доктором экономических наук стал Вячеслав Кыргысович Севек (род. 22.03.1966) (фото 3).

Он родился в с. Элегест Чеди-Хольского кожууна Республики Тыва. В 1999 г. в Санкт-Петербургском государственном архитектурно-строительном институте защитил диссертацию «Экономические особенности применения лизинга для строительных предприятий (на примере Республики Тыва)» на соискание ученой степени кандидата экономических наук (Севек, 1999). В 2015 г. в том же университете, спустя 16 лет, защитил диссертацию на тему «Формирование организационно-экономического механизма развития жилищного строительства в регионах» на соискание ученой степени доктора экономических наук» (Севек, 2015b).

Автор более 190 научных трудов, включая 9 монографий, учебники и учебные пособия. Наиболее заметными публикациями В.К. Севека являются монографии «Организационно-экономические аспекты управления экономическим развитием строительных организаций на региональном рынке жилищного строительства» (Севек, 2013) и «Прогнозирование инвестиционных и производственных возможностей строительных организаций» (Севек, Манчык-Сат, 2014). Ученый специализируется на исследовании проблем экономики строительства в регионе.

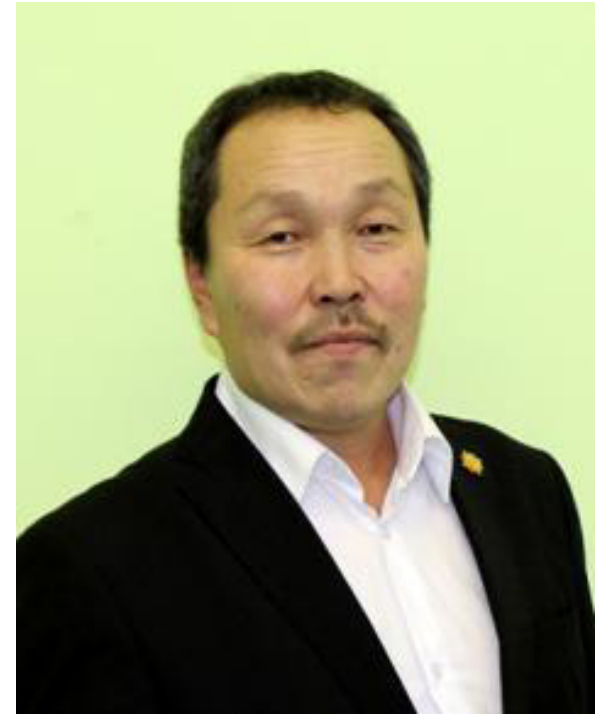

Фото 3. Вячеслав Кыргысович Севек. Фото из архива ТИКОПР СО РАН.

Photo 3. Vyacheslav Kyrgysovich Sevek. Photo from the archive of TIENR SB RAS. 
В марте 1986 г. на базе двух лабораторий - экономической и Тувинской геологической лаборатории Института геологии и геофизики СО АН СССР - открылся Тувинский комплексный отдел Сибирского отделения Академии наук СССР.

В его составе была создана лаборатория экономических исследований. Первый ее заведующий доктор экономических наук Г. И. Ханин руководил до 1989 г. С апреля 1994 г. лаборатория была преобразована в лабораторию региональной экономики ТКО СО РАН, затем - Тувинского института комплексного освоения природных ресурсов СО РАН.

Лабораторией на протяжении всех этих лет заведовали:

1986-1989 гг. - д. э. н. Г. И. Ханин,

1989-2000 гг., 2009 г., 2013-2014 гг. - к. э. н. Г. Ф. Балакина,

2000-2005 гг. - к. т. н. Т. Х. Самданчап,

2005-2009 гг. - к. с. н. Т. М. Ойдуп,

2010-2013 гг., 2014 г. - по наст. время - к. э. н. Д. Ф. Дабиев.

Сотрудники лаборатории участвовали в разработке долгосрочных схем развития и размещения производительных сил республики и других документов, проводили работу по популяризации экономических знаний в трудовых коллективах предприятий и организаций Тувы, входили в творческие коллективы разработчиков Стратегии развития Республики Тыва до 2020 г. и до 2030 г.; долгосрочных и среднесрочных программ развития региона и отраслей; Стратегии развития Сибири (2010 г.). Так, сотрудниками указанной лаборатории под руководством Г. И. Ханина была разработана концепция развития Тувы до 2000 г. (1986-1987 гг.), «в которой предусматривалось использование рыночных механизмов, рычагов и методов. Эта концепция не получила официального статуса и осталась научной прогнозной разработкой перспектив развития региона» (Балакина, Бегзи, 2016: 222).

Учеными за эти годы написаны более 250 научных трудов, в том числе 18 монографий, а также четыре издания учебника «География Тувы», поскольку среди сотрудников экономической лаборатории есть специалисты, работающие на стыке наук экономики и географии, то есть занимающиеся экономической географией (География Тувинской ..., 1989; География Республики Тыва, 1993, 2006; География Тувы: ..., 2019).

В настоящее время в лаборатории работают доктор экономических наук Г. Ф. Балакина и четыре кан-

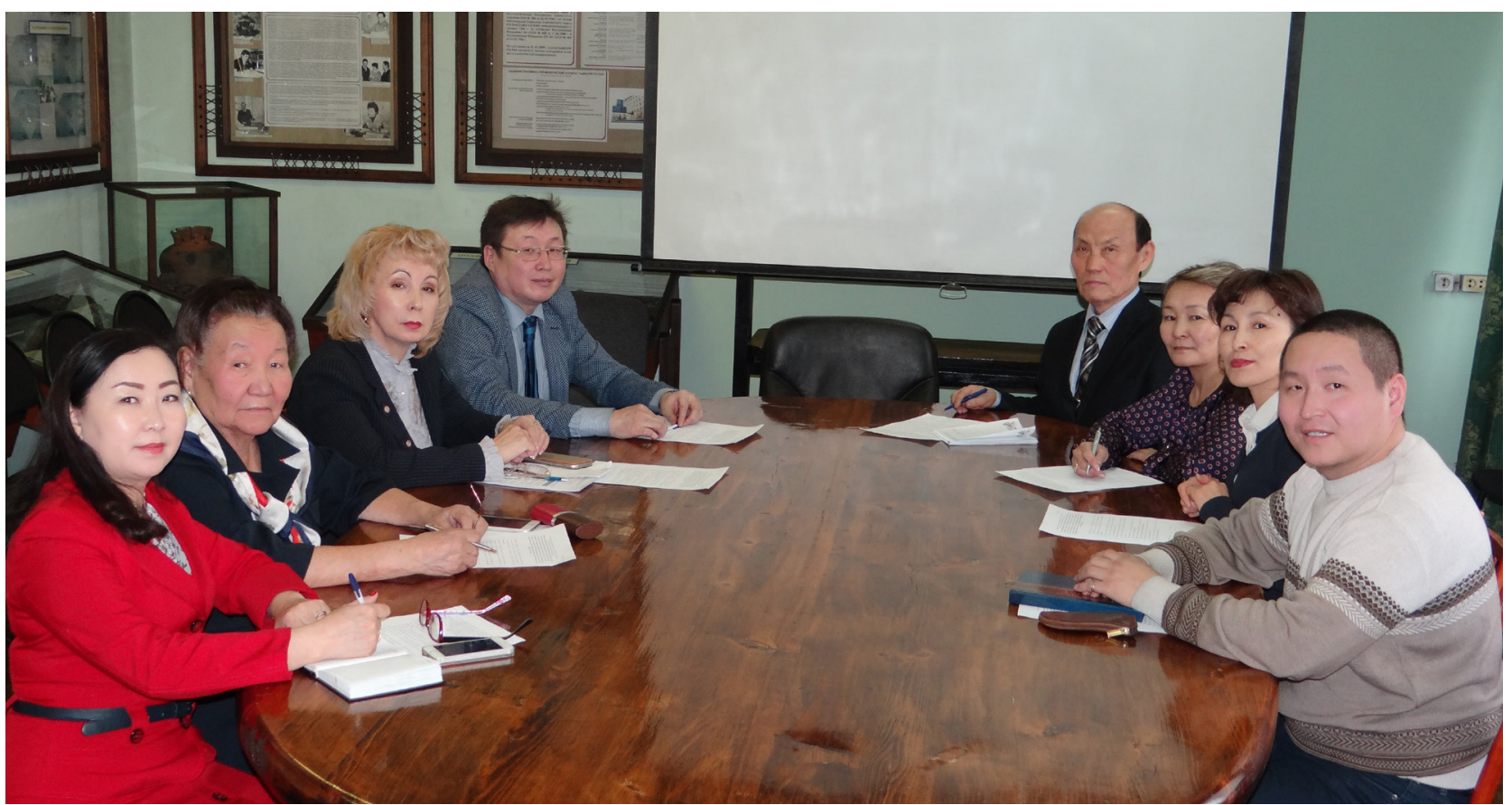

Фото 4. Сотрудники лаборатории региональной экономики ТувИКОПРСО РАН на методологическом семинаре, 2019 г. Фото Ю. Ю. Самбыла.

Photo 4. Staff of the laboratory of regional economy, TIENR SB RAS, at a methodology seminar, 2019. Photo by Yu.Yu. Sambyla. 
дидата экономических наук: Х. Б. Бадарчы, Д. Ф. Дабиев, В. О. Ооржак, Ш. Ч. Соян (фото 4), исследующие проблемы и перспективы развития Республики Тыва с применением геоинформационных технологий, вопросы эффективности освоения месторождений минерального сырья региона.

\section{Создание базы подготовки специалистов (1997-2005 г2.)}

Отличительной особенностью второго этапа является укрепление базы экономической науки с началом выпуска специалистов с высшим экономическим образованием в республике. До этого времени значительная часть рабочих мест, требующих экономических знаний замещалась практиками, имеющими высшее образование неэкономического профиля. Началом данного этапа мы считаем 1997 г., поскольку именно в это время сразу несколько вузов открыли обучение студентовэкономистов в Туве. Обучение экономическим специальностям проводилось на базе экономических факультетов филиалов Хакасского госуниверситета им. Н. Ф. Катанова (ХГУ), Сибирского университета потребительской кооперации (СибУПК), Восточно-Сибирского государственного института культуры (ВСГАКИ). Также в 1997 г. открыта межвузовская кафедра экономики и управления Тувинского государственного университета (ТувГУ), в рамках работы которой решались организационные вопросы создания филиала ХГУ в г. Кызыл и выпуска экономистов с высшим образованием в ТувГУ (заведующая кафедрой А. И. Маады, секретарь А. Л. Монгуш).

Важным событием стало открытие экономического факультета ТувГУ в 2003 г., который, например, за 2004-2019 гг. подготовил более 1430 экономистов с высшим образованием. Более 15 из них занялись преподавательской работой и научными исследованиями. Деканом данного факультета почти бессменно работает д. э. н. В. К. Севек, заслугой которого является стабильный выпуск специалистов и привлечение преподавателей и сотрудников к научным исследованиям. Ученые-экономисты, упомянутые ранее, - все принимали участие в разные годы в подготовке специалистов в ТувГУ.

Также к значимым изменениям относится открытие аспирантуры по экономике в Тувинском государственном университете (2003 г.) и ТувИКОПР СО РАН (2004 г.), в которых прошли обучение 36 специалистов. Как отмечает В. К. Севек, «со дня создания экономического факультета ТувГУ (2003 г.) и по настоящее время были подготовлены 11 кандидатов наук, из них 5 чел. кандидатскую диссертацию подготовили при аспирантуре кафедры экономики и менеджмента ТувГУ, а 6 чел. - в других вузах» (Севек, 2015a: 190-191). Защитившиеся преподаватели практически в полном составе работают на двух кафедрах экономического факультета ТувГУ - экономики и менеджмента и бухучета, анализа и аудита.

В аспирантуре ТувИКОПР СО РАН по экономике за 2004-2016 гг. прошли обучение 11 человек, из них с защитой диссертации - 1 чел. (Д. Ф. Дабиев в 2009 г., см.: Дабиев, 2009), с предоставлением диссертации -3 чел., пятеро из окончивших аспирантуру пошли работать в науку.

Для периода с конца 1990-х годов по настоящее время характерной чертой рынка труда Тувы стала конкуренция претендентов с высшим экономическим образованием на замещение вакансий по экономическим специальностям. В настоящее время специалисты, получившие дипломы в рассматриваемый период, составляют профессиональное ядро в сфере управления предприятиями, отраслями, финансовыми организациями, министерствами и ведомствами.

Существенным является привлечение органами управления разработок ученых при формировании концептуальных положений перспективного развития экономики Тувы. А именно: Государственная программа социально-экономического развития Республики Тыва до 2010 г. (2001 г.), Стратегия развития Республики Тыва на период до 2020 г. (2007 г.), Стратегия социально-экономического развития Республики Тыва до 2030 г. (2018 г.), которые позволяют увязать цели долгосрочного развития Тувы с имеющимися ресурсами, решать инфраструктурные проблемы, включая проблему транспортной изолированности республики, целенаправленно развивать производительные силы региона, повышать уровень и качество жизни населения республики.

Следует отметить востребованность квалифицированных ученых-экономистов органами управления республики. Так, кандидаты экономических наук руководили рядом региональных министерств: Г. Ф. Балакина была заместителем министра экономики в 2000-2004 гг., возглавляла в 2004-2007 гг. министерство экономического развития республики, В. О. Ооржак - министерство промышленности РТ в 1998-2007 гг., К. Б. Саган-оол был заместителем руководителя и руководителем Службы по тарифам РТ в 2002-2007 гг., в 2008-2012 гг. - министр энергетики и промышленности, с 2018 г. и по настоящее время - мэр г. Кызыла; В. К. Севек - начальник управления капитального строительства Правительства Республики Тыва (2008-2009 гг.); Х. Б. Бадарчы- заместитель министра экономики РТ 
в 2013-2016 гг., а к. э. н. Ш. В. Кара-оол является Главой Республики Тыва с 2007 г. по настоящее время.

\section{Расширение тематики экономических исследований с 2006 г.}

Современный этап развития экономической науки в Туве отличается значительным количеством специалистов с высшим экономическим образованием, исследователей с учеными степенями. В 2019 г. в научных организациях, сфере управления и отраслях экономики и социальной сферы республики трудятся 18 кандидатов и 2 доктора экономических наук. Характерным является участие, а в ряде случае, руководство разработкой стратегических направлений перспективного развития региона. В частности, Стратегия социально-экономического развития Республики Тыва до 2030 г. разработана при активном участии сотрудников лаборатории региональной экономики ТувИКОПР СО РАН под руководством автора этой статьи.

У ученых экономистов расширились возможности информирования научной общественности о полученных результатах - начали выходить два научных журнала «Вестник ТувГУ: Социальные и гуманитарные науки» (издается с 2009 г.) и «Природные ресурсы, среда и общество», где есть раздел «Экономика» (издается ТувИКОПР СО РАН с 2019 г.). Существенно возросла публикационная активность, в том числе и благодаря материальному стимулированию в виде выплат премий за публикации и рейтинговых надбавок.

Сейчас можно говорить о достойном среднем уровне публикационной активности сотрудников лаборатории региональной экономики ТувИКОПР СО РАН в сообществе экономистов региона (табл.). Признанием значимости научного уровня исследований является также членство ученых в редакциях научных журналов: сотрудники лаборатории входят в состав редакционных коллегий четырех научных журналов - трех российских и одного зарубежного: International Journal of Business and Economics Research (IJBER, CША) и «Новые исследования Тувы» (Россия), «Региональная экономика: теория и практика» (Россия), «Природные ресурсы, среда и общество» (Россия).

Таблица. Публикационная активность сотрудников лаборатории региональной экономики ТувИКОПР СО РАН, по данным РИНЦ за 2014-2019 г2.

Table. Publications authored by staff of the laboratory of regional economy, TIENR SB RAS, in 2014-2019

\begin{tabular}{|c|c|c|c|c|}
\hline ФИО & $\begin{array}{c}\text { Число публикаций } \\
\text { в РИНЦ }\end{array}$ & $\begin{array}{c}\text { Число ссылок } \\
\text { из РИНЦ на } \\
\text { опубликованные } \\
\text { работы }\end{array}$ & $\begin{array}{c}\text { Число ссылок на } \\
\text { работы автора из } \\
\text { всех публикаций }\end{array}$ & $\begin{array}{c}\text { Индекс Хирша по } \\
\text { всем публикациям } \\
\text { на elibrary.ru }\end{array}$ \\
\hline Балакина Г. Ф. & 44 & 117 & 330 & 11 \\
\hline Ооржак В. О. & 24 & 31 & 55 & 5 \\
\hline Дабиев Д. Ф. & 60 & 48 & 161 & 8 \\
\hline Соян Ш. Ч. & 30 & 42 & 60 & 8 \\
\hline Бадарчи Х. Б. & 8 & 19 & 60 & 5 \\
\hline Кылгыдай А. Ч. & 26 & 29 & 68 & 5 \\
\hline
\end{tabular}

Необходимо подчеркнуть, что отмеченные выше успехи в развитии экономических исследо- 
ваний, не отменяют трудности, с которыми встречаются ученые. К сдерживающим факторам экономических исследований можно отнести: отсутствие в регионе диссертационного совета, слабое финансирование межрегиональных контактов ученых, низкие материальные стимулы повышения научной квалификации, ограниченность возможностей для публикации в высоко рейтинговых изданиях. Отсутствие официально признанных концептуальных проработок перспектив развития экономической науки в республике, недостаток специалистов высокой научной квалификации- докторов наук - можно отнести к недостаткам современного этапа экономических исследований. Это существенно ограничивает качество экономических исследований. Для усиления потенциала научных исследований ТувГУ и ТувИКОПР СО РАН привлекают ученых из других регионов: А. Н. Асаул (г. СанктПетербург), Ю. Г. Полулях (г. Саратов), А. И. Шадрин (г. Красноярск), Г. И. Поподько (г. Красноярск), Н. И. Пляскина (г. Новосибирск).

На современном этапе развития экономической науки произошел значительный рост выпуска монографий, статей, по которым можно составить объемную характеристику социально-экономических процессов в Туве, их динамики, тенденций, вызовов, стоящих перед экономикой региона. Среди наиболее заметных монографий, кроме уже названных работ Ю. Г. Полуляха и В. К. Севека, можно отметить несколько работ Г. Ф.Балакиной (Балакина, 2009b, 2012; Балакина, Кылгыдай, 2015; Балакина, Бегзи, 2016) и Д. Ф. Дабиева и под его редакцией (Дабиев, 2011; Управление ..., 2012 ; Дабиев, Ягольницер, 2012), в которых отражены актуальные направления регулирования регионального развития, инструменты управления региональными процессами и вовлечением в хозяйственный оборот минерально-сырьевого потенциала Тувы и соседних территорий.

\section{Заключение}

За более чем 65-летнюю историю развития экономической науки в Республике Тыва и 45-летний ее академический период достигнуто следующее: созданы основы (организационные, информационные, институциональные) для формирования и отработки стратегических направлений совершенствования социально-экономических процессов в регионе; написаны и опубликованы десятки монографий и сотни научных статей, посвященных анализу проблем и тенденций формирования социально-экономических процессов в регионе.

На начало 2020 г. экономическими исследованиями занимались 41 сотрудник: 11 чел. - в Тувинском институте гуманитарных и прикладных социально-экономических исследований (ТИГПИ, бывш. ТНИИЯЛИ) (2 кандидата экономических наук), 8 чел. - в ТувИКОПР СО РАН (4 кандидата и 1 доктор экономических наук) и 22 чел. - в ТувГУ (11 кандидатов и 1 доктор экономических наук). Увеличение числа дипломированных ученых, а также количество их работ, позволяет говорить о начале формирования научных школ в Республике Тыва. Здесь явно выделяются две школы: академическая, включающая труды сотрудников лаборатории региональной экономики ТувИКОПР СО РАН «Формирование стратегических направлений социально-экономического развития регионов» (основатель - д. э. н. Г. Ф. Балакина), и вузовская - «Проблемы эффективности модернизационных и инновационных процессов», представленная сотрудниками экономического факультета Тувинского госуниверситета (основатель - д. э. н. В. К. Севек).

Особенности географического положения республики, оторванность от основных транспортных путей, недостаток финансовых средств продолжают определять сложное развитие научно-образовательного комплекса республики. Но возможности для развития есть, и мы их неоднократно указывали в наших работах (Балакина, 2008: 67; Балакина, 2009: 38). Добавим к этому, что в целях повышения эффективности научных исследований вообще и экономической науки, в частности, в Республике Тыва необходимо повысить внимание к проблемам перехода к «экономике знаний», формированию новых отраслей подготовки кадров, отвечающих глобальным современным вызовам, снизить отставание параметров уровня жизни и качественного состава научных сотрудников и преподавателей. Целесообразно разработать и осуществить систему мер, включая инвестиционные, законодательно-нормативные и социальные мероприятия, по увеличению числа докторов и кандидатов; увеличить объем финансирования научных исследований, включая развитие приборной и технической оснащенности научных организаций.

Основными направлениями интеграции науки и образования в области экономических наук, по нашему мнению, должны стать создание и легитимизация новых инструментов интеграции науки и образования: возобновление совместных экономических исследований ТувИКОПР СО РАН и ТувГУ; 
для предпринимателей, предприятий и организаций - консалтинговой службы как практики для студентов 4-5 курсов экономических специальностей; создание единой базы данных проведенных экономических исследований в целях исключения дублирования и консолидации ученых для поиска путей решения проблем республики. Здесь возможно создание свода данных в отделе науки Минобрнауки республики или Минэкономики РТ, доступной широкому кругу пользователей. Также целесообразно предусмотреть документальное оформление баз данных - авторских свидетельств на сформированные базы данных - по развитию отраслей экономики, организаций реального сектора экономики, их оснащенности машинами и механизмами.

Мы также считаем, что необходимо формирование подразделения, занимающегося организацией экономических исследований и инновационных разработок как в структуре исполнительных органов власти, так и в научно-образовательном комплексе. Это может быть дирекция инновационного развития или проектный офис «Наука - будущему Тувы». Возможно формирование отдела экономических исследований на базе консолидации исследований академических научных учреждений и экономических кафедр ТувГУ с целью устранения дублирования (к 2025 г.), открытие института экономического профиля в составе научного центра Сибирского отделения РАН (к 2027-2030 гг.).

\section{СПИСОК ЛИТЕРАТУРЫ}

Балакина, Г. Ф. (2008) Перспективы развития Республики Тыва: инновационная стратегия // ЭКО. № 7. С. 60-68.

Балакина, Г. Ф. (2009а) Особенности инновационного пути развития депрессивного региона // Региональная экономика: теория и практика. № 4 (97). С. 31-39.

Балакина, Г. Ф. (2009b) Стратегии развития депрессивного региона / отв. ред. С. В. Парамонова. Кызыл : ТувИКОПР СО РАН. 344 с.

Балакина, Г. Ф. (2011) Становление экономической науки в Туве: проблемы и перспективы // Региональные аспекты интеграции науки и образования: проблемы, перспективы развития. Материалы Всероссийской научнопрактической конференции / отв. ред. В. К. Севек. Кызыл : Изд-во ТывГУ. 302 с. С. 69-78.

Балакина, Г. Ф. (2012) Депрессивные регионы: формирование стратегий социально-экономического развития / отв. ред. Е. Б. Кибалов. Кызыл : ТувИКОПР СО РАН. 218 с.

Балакина, Г. Ф., Кылгыдай, А. Ч. (2015) Этнорегиональные модели адаптации к рынку труда в Туве / отв. ред. Л. В. Корель. Кызыл : ТувИКОПР СО РАН. 160 с.

Балакина, Г. Ф., Бегзи, А. Д. (2016) Экономика Тувы: возможные стратегии развития. Кызыл : ТувИКОПР СО PAH. 380 c.

Бегзи, А. Д., Балакина, Г. Ф. (2016) К. О. Шактаржик - первый ученый-географ Тувы // Материалы республиканской научно-практической конференции «География Тувы: образование и наука» (к 85-летию первого ученого географа Тувы К. О. Шактаржика) / отв. ред. В. И. Лебедев. Кызыл : ТувИКОПР СО РАН. 148 с. С. 10-13.

Библиографический указатель авторефератов диссертаций (1941-1999 гг.) (2000) / составитель 3. М. Монгуш. Кызыл : ТИГИ. 109 с.

География Тувинской АССР (1989) : учебное пособие для 8-го кл. / В. А. Гребнева, К. О. Шактаржик. Кызыл : Тувинское книжное издательство. 133 с.

География Республики Тува (1993) : учеб. пособие для 9-го кл. / К. О. Шактаржик. Кызыл : Тувинское книжное издательство. 127 с.

География Республики Тыва (2006) : учебное пособие для IX класса / К. О. Шактаржик, А. Ч. Кылгыдай, О. С. Дамдын. Кызыл : Тувинское книжное издательство. 150 с.

География Тувы: природа, население и хозяйство (2019): учебное пособие для 8 класса общеобразовательных организаций / под редакцией С. С. Курбатской. М. : ООО «Русское слово - учебник». 128 с.

Городское население Тувинской АССР (1981) / отв. ред. В. И. Бойко. Новосибирск : Наука. 224 с.

Дабиев, Д. Ф. (2009) Экономическая оценка эффективности освоения минеральных ресурсов региона (на примере Республики Тыва) : автореф.... к. э. н. Новосибирск. 19 с.

Дабиев, Д. Ф. (2011) Управление минерально-сырьевым потенциалом региона (на примере Республики Тыва). Кызыл : Изд-во ТувГУ. 123 с.

Дабиев, Д. Ф., Ягольницер, М. А. (2012) Экономическая оценка эффективности освоения минерально-сырьевых ресурсов Тувы. Кызыл : ТувИКОПР СО РАН. 110 с.

Заслуженные люди Тувы XX века. Государственная книга Республики Тыва (2004). Кызыл : Тувинское книжное издательство. 341 с.

Ковалев, А. Г. (1963) Создание и развитие экономики социализма в Туве : автореф. дисс. ... канд. эк. н. М. 19 с. 
Копеел, В. А. (1968) Особенности создания социалистической экономики в Туве : автореф. дисс. ... к. эк. н. М. 29 c.

Копеел, В. А. (1971) Создание социалистической экономики в Туве. Кызыл : Тувинское книжное изд-во. 197 с.

Копеел, А. В. (1991) Взаимодействие внутрифирменного и рыночного ценообразования в условиях современного капитализма : автореф. дисс. ... к. эк. н. 25 с.

Молодежь Тувы. Социальный портрет (1988) / отв. ред. Ю. Л. Аранчын. Новосибирск : Наука. 194 с.

Наша Тува (1981): учебное пособие для средней школы / В. А. Копеел, В. Ч. Очур, В. А. Дубровский, под ред. В. А. Бузыкаева. Кызыл: Тувинское книжное издательство. 135 с.

Ойдуп, Т. М., Полулях, Ю. Г., Ададимова, Л. Ю. (2011) Состояние социальной инфраструктуры Сибирского федерального округа / отв. ред. А. К. Михальченко. Кызыл : ТувИКОПР СО РАН. 78 с.

Осипова, В. В. (1963) История социалистического преобразования хозяйства в Туве : автореф. дисс. ... к. эк. н. M. 19 c.

Очерки социального развития Тувинской АССР (1983) / отв. ред. Ю. Л. Аранчын. Новосибирск : Наука. 262 с.

Полулях, Ю. Г. (1974) Пути повышения использования машинно-тракторного парка в земледелии (на примере совхозов Тувинской АССР) : автореф. дисс.... к. эк. н. М. 19 с.

Полулях, Ю. Г. (1993) Теоретические и методические основы экономической оценки сельскохозяйственных угодий и проблемы ее использования : автореф. дисс.... д-ра эк. н. Новосибирск. 40 с.

Полулях, Ю. Г., Ойдуп, Т. М., Лебедев, В. И., Ададимова, Л. Ю. (2007) Региональные аспекты стимулирования роста промышленного производства налоговыми преференциями в Республике Тыва / науч. ред. А. К. Михальченко. Кызыл : ТувИКОПР СО РАН. 100 с.

Русско-тувинский словарь общественно-политических терминов (1966) / отв. ред. К. Н. Диига. Кызыл : Тувинское книжное изд-во. 364 с.

Русско-тувинский словарь общественно-политических терминов (1979). 2-е изд. / отв. ред. Д. А. Монгуш. Кызыл: Тувинское книжное издательство. 377 с.

Севек, В. К. (1999) Экономические особенности применения лизинга для строительных предприятий (на примере Республики Тыва) : автореф. дисс. ... канд. эк. н. СПб. 24 с.

Севек, В.К. (2013) Организационно-экономические аспекты управления экономическим развитием строительных организаций на региональном рынке жилищного строительства. Кызыл: Изд-во ТувГУ. 198 с.

Севек, В. К. (2015а) Развитие экономической науки в Республике Тыва // Вестник ТувГУ. Социальные и гуманитарные науки. № 1. С. 188-192.

Севек, В. К. (2015b) Формирование организационно-экономического механизма развития жилищного строительства в регионах : автореф. дисс. ... д-ра эк. н. СПб. 39 с.

Севек, В. К., Манчык-Сат, Ч. С. (2014) Прогнозирование инвестиционных и производственных возможностей строительных организаций. Кызыл: Изд-во ТувГУ. 180 с.

Солдатов, В. П. (1967) Размещение и специализация сельского хозяйства Тувинской АССР : автореф. дисс. ... к. эк. н. М. 20 с.

Тинмей, Д. Л. (1977) Экономические проблемы формирования и использования природных ресурсов региона (на примере Восточной Сибири) : автореф. дисс. ... канд. эк. н. М. 15 с.

Тульчинский, Л. И. (1961) Роль государственного бюджета СССР в социалистических преобразованиях и дальнейшем развитии экономики и культуры Советской Тувы : автореф.... канд. эк. н. М. 22 с.

Управление минерально-сырьевым потенциалом приграничных территорий Тувы и Западной Монголии (2012) / под редакцией Д. Ф. Дабиева. Кызыл : ТувИКОПР СО РАН. 196 с.

Харунов, Р. Ш. (2009) Формирование интеллигенции в Тувинской Народной Республике (1921-1944). Абакан : ООО «Журналист». 144 с.

Харунова, М. М.-Б. (2011) Социально-политическое развитие Тувы в середине XX века. Новосибирск : Наука. 139 c.

Шактаржик, К. О. (1966) Земельные и водные ресурсы Тувинской АССР: автореферат докл., прочит. на Геогр. секции Моск. о-ва испытателей природы 17 ноября 1965 // Бюллетень моск. о-ва испыт. природы. М. : Изд-во МГУ им. М. В. Ломоносова. Отдел. геол. Т. 41, вып. 2. С. 147-149.

Шактаржик, К. О., Бегзи, А.Д., Урбанаев, Л.Л.(1980) Узловые проблемы развития народного хозяйства Тувинской АССР // Проблемы развития хозяйства Ангаро-Енисейского региона. Материалы Всесоюзной конференции по развитию производительных сил Сибири / отв. ред. Г. И. Фильши, Ю. М. Березкин. Иркутск : Изд-во «ВосточноСибирская правда». 247 с. С. 182-192.

Экономика Тувинской АССР (1973) / отв. ред. С. В. Клопов. Кызыл : Тувинское книжное издательство. 377 с. Дата поступления: 05.03.2020 2. 
Balakina, G. F. (2008) Perspektivy razvitiia Respubliki Tyva: innovatsionnaia strategiia [Republic of Tiva Development Perspectives: Innovation Strategy]. ECO, no. 7, pp. 60-68. (In Russ.).

Balakina, G. F. (2009a) Osobennosti innovatsionnogo puti razvitiia depressivnogo regiona [The path of innovative development for a depressed region]. Regional'naia ekonomika: teoriia i praktika, no. 4 (97), pp. 31-39. (In Russ.).

Balakina, G. F. (2009b) Strategii razvitiia depressivnogo regiona [Strategies for the development of a depressive region] / ed. by S. V. Paramonov. Kyzyl, TuvIKOPR SO RAN. 344 p. (In Russ.).

Balakina, G. F. (2011) Stanovlenie ekonomicheskoi nauki v Tuve: problemy i perspektivy [The rise of the science of economics in Tuva: problems and prospects]. In: Regional'nye aspekty integratsii nauki i obrazovaniia: problemy, perspektivy razvitiia [Regional aspects of integration of science and education: problems and prospects of development]. Proceedings of the Russian scientific and practical conference / ed. by V. K. Sevek. Kyzyl, Izd-vo TyvGU. 302 p. Pp. 69-78. (In Russ.).

Balakina, G. F. (2012) Depressivnye regiony: formirovanie strategii sotsial'no-ekonomicheskogo razvitiia [Depressive regions: the rise of socio-economic development strategies] / ed. by E. B. Kibalov. Kyzyl, TuvIKOPR SO RAN. 218 p. (In Russ.).

Balakina, G. F. and Kylgydai, A. Ch. (2015) Etnoregional'nye modeli adaptatsii k rynku truda v Tuve [Ethno-regional models of adaptation to the labour market in Tuva]. Kyzyl, TuvIKOPR SO RAN. 160 p. (In Russ.).

Balakina, G. F. and Begzi, A. D. (2016) Ekonomika Tuvy: vozmozhnye strategii razvitiia [The economy of Tuva: possible strategies of development]. Kyzyl, TuvIKOPR SO RAN. 380 p. (In Russ.).

Begzi, A. D. and Balakina, G. F. (2016) K. O. Shaktarzhik - pervyi uchenyi-geograf Tuvy [K. O. Shaktarzhik, the first geographer of Tuva]. In: Materialy respublikanskoi nauchno-prakticheskoi konferentsii «Geografia Tuvy: obrazovanie $i$ nauka» (k 85-letiiu pervogo uchenogo geografa Tuvy K. O. Shaktarzhika) [Proceedings of the regional conference "Geography of Tuva: education and science" (for the 85th anniversary of the first scientist geographer of Tuva K. O. Shaktarzhika)] / ed. by V. I. Lebedev. Kyzyl, TuvIKOPR SO RAN. 148 p. Pp. 10-13. (In Russ.).

Bibliograficheskii ukazatel' avtoreferatov dissertatsii (1941-1999 gg.) [Bibliographic index of dissertation abstracts (1941-1999)] (2000) / comp. by Z. M. Mongush. Kyzyl, TIGI. 109 p. (In Russ.).

Geografiia Tuvinskoi ASSR [Geography of the Tuvan ASSR] (1989) : textbook for the $8^{\text {th }}$ grad. / V. A. Grebneva and K. O. Shaktarzhik. Kyzyl, Tuvan book publishing house. 133 p. (In Russ.).

Geografiia Respubliki Tuva [Geography of the Republic of Tuva] (1993) : textbook for the $9^{\text {th }}$ grad. / K. O. Shaktarzhik. Kyzyl, Tuvan book publishing house. 127 p. (In Russ.).

Geografiia Respubliki Tuva [Geography of the Republic of Tuva] (2006) : textbook for the $9^{\text {th }}$ grad. / K. O. Shaktarzhik, A. Ch. Kylgydai and O. S. Damdyn. Kyzyl, Tuvan book publishing house. 150 p. (In Russ.).

Geografiia Tuvy: priroda, naselenie i khoziaistvo [Geography of Tuva: nature, population and economy] (2019): textbook for the $8^{\text {th }}$ grad. / ed. by S. S. Kurbatskaya. Moscow, OOO «Russkoe slovo - uchebnik». 128 p. (In Russ.).

Gorodskoe naselenie Tuvinskoi ASSR [Urban population of the Tuvan ASSR] (1981) / ed. by V. I. Boiko. Novosibirsk, Nauka. 224 p. (In Russ.).

Dabiev, D. F. (2009) Ekonomicheskaia otsenka effektivnosti osvoeniia mineral'nykh resursov regiona (na primere Respubliki Tyva) [Economic assessment of the efficiency of mineral resources development in the region: the case of the Republic of Tuva)] : Thesis of Diss.... Candidate of Economy Sciences. Novosibirsk. 19 p. (In Russ.).

Dabiev, D. F. (2011) Upravlenie mineral'no-syr'evym potentsialom regiona (na primere Respubliki Tyva) [Management of the mineral resource potential of the region: the case of the Republic of Tuva)]. Kyzyl, Izd-vo TuvGU. 123 p. (In Russ.).

Dabiev, D. F. and Iagol'nitser, M. A. (2012) Ekonomicheskaia otsenka effektivnosti osvoeniia mineral'no-syr'evykh resursov Tuvy [Economic assessment of the efficiency of development of mineral resources of Tuva]. Kyzyl, TuvIKOPR SO RAN. $110 \mathrm{p}$. (In Russ.).

Zasluzhennye liudi Tuvy XX veka. Gosudarstvennaia kniga Respubliki Tyva [Honored people of Tuva of the XX century. State book of the Republic of Tuva] (2004). Kyzyl, Tuvan book publishing house. 341 p. (In Russ.).

Kovalev, A. G. (1963) Sozdanie i razvitie ekonomiki sotsializma v Tuve [The rise and development of Socialist economy in Tuva]: Thesis of Diss.... Candidate of Economy Sciences. Moscow. 19 p. (In Russ.).

Kopeel, V. A. (1968) Osobennosti sozdaniia sotsialisticheskoi ekonomiki v Tuve [Aspects of creating a Socialist economy in Tuva] : Thesis of Diss.... Candidate of Economy Sciences. Moscow. 29 p. (In Russ.).

Kopeel, V.A. (1971) Sozdanie sotsialisticheskoi ekonomiki v Tuve [The establishment of a socialist economy in Tuva]. Kyzyl, Tuvan book publishing house. 197 p. (In Russ.).

Kopeel, A. V. (1991) Vzaimodeistvie vnutrifirmennogo $i$ rynochnogo tsenoobrazovaniia $v$ usloviiakh sovremennogo kapitalizma [Interaction of intra-firm and market pricing in the conditions of modern capitalism]: Thesis of Diss.... Candidate of Economy Sciences. Moscow. 25 p. (In Russ.).

Molodezh' Tuvy. Sotsial'nyi portret [The Youth of Tuva: A social portrait] (1988) / ed. by Yu. L. Aranchyn. Novosibirsk, Nauka. 194 p. (In Russ.).

Nasha Tuva [Our Tuva] (1981): a textbook for secondary schools / V. A. Kopeel, V. Ch. Ochur and V. A. Dubrovskii, ed. by 
V. A. Buzykaev. Kyzyl, Tuvan book publishing house. 135 p. (In Russ.).

Oidup, T. M., Poluliakh, Yu. G. and Adadimova, L. Yu. (2011) Sostoianie sotsial'noi infrastruktury Sibirskogo federal'nogo okruga [The state of social infrastructure in the Siberian Federal district] / ed. by A. K. Mikhal'chenko. Kyzyl, TuvIKOPR SO RAN. 78 p. (In Russ.).

Osipova, V. V. (1963) Istoriia sotsialisticheskogo preobrazovaniia khoziaistva $v$ Tuve [History of the Socialist transformation of the economy in Tuva] : Thesis of Diss.... Candidate of Economy Sciences. Moscow. 19 p. (In Russ.).

Ocherki sotsial'nogo razvitiia Tuvinskoi ASSR [Essays on social development of the Tuvan ASSR] (1983) / ed. by Yu. L. Aranchyn. Novosibirsk, Nauka. 262 p. (In Russ.).

Poluliakh, Yu. G. (1974) Puti povysheniia ispol'zovaniia mashinno-traktornogo parka $v$ zemledelii (na primere sovkhozov Tuvinskoi ASSR) [Ways to increase the use of machine and tractor fleet in agriculture: the case of the Tuvan ASSR)] : Thesis of Diss.... Candidate of Economy Sciences. Moscow. 19 p. (In Russ.).

Poluliakh, Yu. G. (1993) Teoreticheskie i metodicheskie osnovy ekonomicheskoi otsenki sel'skokhoziaistvennykh ugodii i problemy ee ispol'zovaniia [Theoretical and methodological foundations of economic assessment of agricultural land and problems of its use] : Thesis of Diss.... Doctor of Economy Sciences. Novosibirsk. 40 p. (In Russ.).

Poluliakh, Yu. G., Oidup, T. M., Lebedev, V. I. and Adadimova, L. Yu. (2007) Regional'nye aspekty stimulirovaniia rosta promyshlennogo proizvodstva nalogovymi preferentsiiami $v$ Respublike Tyva [Regional aspects of stimulating the growth of industrial production by tax preferences in the Republic of Tuva] / ed. by A. K. Mikhal'chenko. Kyzyl, TuvIKOPR SO RAN. 100 p. (In Russ.).

Russko-tuvinskii slovar' obshchestvenno-politicheskikh terminov [Russian-Tuvan dictionary of socio-political terms] (1966) / ed. by K. N. Diiga. Kyzyl, Tuvan book publishing house. 364 p. (In Russ.).

Russko-tuvinskii slovar' obshchestvenno-politicheskikh terminov [Russian-Tuvan dictionary of socio-political terms] (1979). $2^{\text {nd }}$ ed. / ed. by D. A. Mongush. Kyzyl, Tuvan book publishing house. 377 p. (In Russ.).

Sevek, V. K. (1999) Ekonomicheskie osobennosti primeneniia lizinga dlia stroitel'nykh predpriiatii (na primere Respubliki Tyva) [Economic features of leasing application for construction enterprises: the case of the Republic of Tuva)] : Thesis of Diss. ... Candidate of Economy Sciences. St. Petersburg. 24 p. (In Russ.).

Sevek, V. K. (2013) Organizatsionno-ekonomicheskie aspekty upravleniia ekonomicheskim razvitiem stroitel'nykh organizatsii na regional'nom rynke zhilishchnogo stroitel'stva [Organizational and economic aspects of managing the economic development of construction organizations on the regional housing market]. Kyzyl, Izd-vo TuvGU. 198 p. (In Russ.).

Sevek, V. K. (2015a) Razvitie ekonomicheskoi nauki v Respublike Tyva [Development of economics in the Republic of Tuva]. Vestnik TuvGU. Sotsial'nye i gumanitarnye nauki, no. 1, pp. 188-192.

Sevek, V. K. (2015b) Formirovanie organizatsionno-ekonomicheskogo mekhanizma razvitiia zhilishchnogo stroitel'stva $v$ regionakh [Setting up an organizational and economic mechanism for the development of housing construction in the regions] : Thesis of Diss.... Doctor of Economy Sciences. St. Petersburg. 39 p. (In Russ.).

Sevek, V. K. and Manchyk-Sat, Ch. S. (2014) Prognozirovanie investitsionnykh i proizvodstvennykh vozmozhnostei stroitel'nykh organizatsii [Forecasting investment and production opportunities of construction organizations]. Kyzyl, Izd-vo TuvGU. 180 p. (In Russ.).

Soldatov, V. P. (1967) Razmeshchenie i spetsializatsiia sel'skogo khoziaistva Tuvinskoi ASSR [Placement and specialization of agriculture in the Tuvan ASSR] : Thesis of Diss.... Candidate of Economy Sciences. Moscow. 20 p. (In Russ.).

Tinmei, D. L. (1977) Ekonomicheskie problemy formirovaniia i ispol'zovaniia prirodnykh resursov regiona (na primere Vostochnoi Sibiri) [Economic problems of the development and use of natural resources in the region: the case of Eastern Siberia)] : Thesis of Diss.... Candidate of Economy Sciences. Moscow. 15 p. (In Russ.).

Tul'chinskii, L. I. (1961) Rol' gosudarstvennogo biudzheta SSSR v sotsialisticheskikh preobrazovaniiakh i dal'neishem razvitii ekonomiki i kul'tury Sovetskoi Tuvy [The Role of the state budget of the USSR in the Socialist transformations and further development of the economy and culture of Soviet Tuva] : Thesis of Diss.... Candidate of Economy Sciences. Moscow. 22 p. (In Russ.).

Upravlenie mineral'no-syr'evym potentsialom prigranichnykh territorii Tuvy i Zapadnoi Mongolii [Management of mineral resource potential of the border territories of Tuva and Western Mongolia] (2012) / ed. by D. F. Dabiev. Kyzyl, TuvIKOPR SO RAN. 196 p. (In Russ.).

Kharunov, R. Sh. (2009) Formirovanie intelligentsii v Tuvinskoi Narodnoi Respublike (1921-1944) [The rise of the intelligentsia in the Tuva people's Republic (1921-1944)]. Abakan, OOO «Zhurnalist». 144 p. (In Russ.).

Kharunova, M. M. (2011) Sotsial'no-politicheskoe razvitie Tuvy v seredine XX veka [Sociopolitical development of Tuva in the mid-twentieth century]. Novosibirsk, Nauka. 135 p. (In Russ.).

Shaktarzhik, K. O. (1966) Zemel'nye i vodnye resursy Tuvinskoi ASSR: avtoreferat dokl., prochit. na Geogr. sektsii Mosk. o-va ispytatelei prirody 17 noiabria 1965 [Land and water resources of the Tuvan ASSR]: Thesis of Diss.... Doctor of Economics. Biulleten' mosk. o-va ispyt. prirody. Moscow, Izd-vo MGU im. M. V. Lomonosova. Otdel. geol. Vol. 41 , issue 2. Pp. 147-149. (In Russ.).

Shaktarzhik, K. O., Begzi, A. D. and Urbanaev, L. L. (1980) Uzlovye problemy razvitiia narodnogo khoziaistva Tuvinskoi 
ASSR [Key problems of development of the national economy of the Tuvan ASSR]. In: Problemy razvitiia khoziaistva AngaroEniseiskogo regiona [Problems of economic development in the Angara-Yenisei region]. Materials of all-Union conference on development of productive forces of Siberia / ed. by G. I. Fil'shi and Yu. M. Berezkin. Irkutsk, Izd-vo «Vostochno-Sibirskaia pravda». 247 p. Pp. 182-192. (In Russ.).

Ekonomika Tuvinskoi ASSR [The economy of Tuvan ASSR] (1973). Ed. by S. V. Klopov. Kyzyl, Tuvan book publishing house. 378 p. (In Russ.).

Submission date: 05.03.2020. 